\title{
Os neologismos e a ampliação lexical nas redes sociais
}

\author{
Los neologismos y la ampliación lexical en las redes sociales
}

Neologisms and lexical enlargement in social networks

\author{
Alexandre António Timbane ${ }^{1}$ \\ Dayanny Marins Coelho ${ }^{2}$
}

\begin{abstract}
Resumo
A língua é dinâmica e recorre ao processo neológico para a sua renovação e manutenção. Este estudo tem como objetivo revisar os conceitos relativos ao léxico, à lexicologia e aos processos de criação de palavras novas (neologismos). Para fundamentar os processos de ampliação do léxico nas redes sociais, discute-se as teorias de Carvalho (2009), Alves (2004), Cristal (2004) e Timbane (2013). Foram informantes 20 frequentadores (7 homens e 13 mulheres) do Facebook na Cidade de Mourinhos. Trata-se de uma pesquisa de qualitativa. Da pesquisa conclui-se que inúmeros processos morfológicos, sintáticos e semânticos são frequentes no Facebook e que o português brasileiro é muito produtivo lexicalmente. Os informantes observados utilizam o Facebook para conversas do dia a dia e de forma informal criando neologismos que na sua maioria são emprestadas por "necessidade" e raramente por "luxo". Foi possível constatar que um número significativo de palavras é de origem inglesa. Os indivíduos costumam mesclar os dois idiomas, ou seja, começam com o português e depois incluem palavras de origem inglesa.
\end{abstract}

Palavras-Chave: Lexicologia; Neologismos; Empréstimos.

\section{Resumen}

La lengua es dinámica y recurre al proceso neológico para su renovación y mantenimiento. Este estudio tiene como objetivo revisar los conceptos relativos al léxico, a la lexicología ya los procesos de creación de palabras nuevas (neologismos). Para fundamentar los procesos de ampliación del léxico en las redes sociales, se discuten las teorías de Carvalho (2009), Alves (2004), Cristal (2004) y Timbane (2013). En la ciudad de Mourinhos fueron informantes 20 asistentes (7 hombres y 13 mujeres) de Facebook en la ciudad de Mourinhos. Se trata de una investigación cualitativa. La investigación se llegó a la conclusión de que numerosos procesos morfológicos, sintácticos y semánticos son comunes en Facebook y portugués de Brasil es muy productivo léxico. Los informantes observados utilizan Facebook para conversaciones de día a día y de forma informal creando neologismos que en su mayoría son prestados por "necesidad" y raramente por "lujo". Es posible constatar que un número significativo de palabras es de origen inglés. Los individuos tienden a fusionar las dos lenguas, es decir, a partir de los portugueses y luego incluyen palabras fuente Inglés.

Palabras claves: Lexicología; Neologismos; Préstamos.

\begin{abstract}
The language is dynamic and uses the neological process for its renewal and maintenance. This study aims to review concepts related to lexicon, lexicology and processes of creation of new words (neologisms). In order to support the processes of expanding the lexicon in social networks, the theories of Carvalho (2009), Alves (2004), Cristal (2004) and Timbane (2013) are discussed. 20 respondents ( 7 men and 13 women) from Facebook in the city of Mourinhos were informants. This is a qualitative research. The research concludes that numerous morphological, syntactic and semantic processes are frequent in Facebook and that Brazilian Portuguese is very
\end{abstract}

\footnotetext{
1 Doutor em Linguística e Língua Portuguesa, Universidade de Integração Internacional da Lusofonia afrobrasileira, Instituto de Humanidades e Letras, Campus dos Malês, Bahia, São Francisco do Conde, email: alexandre.timbane@unilab.edu.br

2 Mestre em Estudos da Linguagem pela Universidade Federal de Goiás, Docente do Ensino Superior, Pesquisadora Independente.
} 
productive lexically. Observed informants use Facebook for day-to-day conversations and informally creating neologisms that are mostly borrowed for "necessity" and rarely for "luxury". It was found that a significant number of words are of English origin. Individuals usually merge the two languages, that is, they begin with Portuguese and then include words of English origin.

Keywords: Lexicology; Neologisms; Loans.

\section{Introdução}

O mundo está mudando e a cultura não fica à margem. A língua está intimamente ligada à cultura e às mudanças culturais que sempre se fazem sentir no cotidiano. As novas tecnologias de informação tendem a crescer no mundo todo facilitando e também, complicando a vida dos cidadãos menos avisados. Isso acontece porque quem não domina as tecnologias de informação fica excluído e em algum momento perde privilégios e facilidades.

O léxico é um dos aspetos linguísticos que mais se evidencia na língua porque ele se desloca de uma língua para a outra, desaparece e reaparece, ganha ou perde sentidos semânticos ou ainda adapta-se aos novos contextos na língua em que é emprestada. Para o presente trabalho, entende-se por redes sociais, o conjunto de programas e aplicativos informáticos que permitem o estabelecimento de relações sociais e culturais entre um grupo de pessoas. Dentre os vários recursos pode-se citar os seguintes exemplos: Facebook, Twitter, Instagram, Google+, Youtube, MySpace, Badoo que $\quad$ são $\quad$ baixados gratuitamente na internet e instalados em computadores, tablets, smarthphones, telefones e outros dispositivos. As redes sociais são mais acessadas por cidadãos que têm acesso às tecnologias, em sua maioria adolescentes e jovens residentes nas zonas urbanas e suburbanas.

A entrada da internet nos computadores, nos smartphones, e sobretudo, nos telefones celulares popularizou cada vez mais as redes sociais e criou uma espécie de "mundo comunicativo globalizado" no qual as pessoas se sentem perto umas das outras, estando distantes apenas por um simples clique.

Hoje as informações circulam com mais rapidez e eficiência por meio dessas redes, desafiando a linguística e exigindo estudos aprofundados que possam permitir o acompanhamento do desenvolvimento, pois "toda inovação tecnológica impacta a forma pela qual as pessoas se comunicam, ninguém pode negar" (RAJAGOPALAN, 2013, p.41). A essa linguagem, Rajagopalan (2013), Cristal (2004) e Hadžiahmetoviü-Jurida (2007) designam por internetês.

Portanto, a presente pesquisa se justifica pelo fato de que a língua está em constante variação (e mudança) impulsionada pelas variáveis sociais, econômicas e culturais. É importante analisar como a língua se comporta sincronicamente para que se possa 
compreender o estado atual. Outra motivação para a presente pesquisa se justifica pela pressão das tecnologias nas últimas décadas na nossa sociedade. A internet se popularizou e pelo menos permite a comunicação entre pessoas usando a língua oral (ex. chamada simples), língua escrita (ex. sms) e (áudio) visual (ex. chamada vídeo que ajuda aos usuários da língua de sinais). O telefone é ao mesmo tempo máquina de filmar, máquina fotográfica, projetor de slides, computador, gravador ou ainda produtor de textos (mensagens de texto). Essas mensagens tendem a imitar a língua oral desviando-se assim, das normas padronizadas pela ortografia.

Nessa comunicação ocorrem formações novas de palavras, de ideias e de significados (neologismos formais, semânticos e empréstimos) vindas, majoritariamente, da língua inglesa como veremos mais adiante. A língua inglesa é a língua das tecnologias e os usuários das redes sociais utilizam com frequência expressões e palavras estrangeiras. Não é por acaso que o nosso português recebeu palavras tais como: printar, tuitar, deletar, facebookar, botar, pendrive, layout, link e ainda acrônimos e siglas do inglês que se transformam em palavras na língua portuguesa, como por exemplo: aids, radar, DNA, GPS, HD, IPOD, DJ, RAP, laser entre várias outras.

No sentido de observar se o uso dos neologismos nas redes sociais constitui um fator de oralidade secundária (CITELLI, 2006; CARVALHO \& KRAMER, 2013), cujo conceito remete ao fato de a linguagem ter agregado uma nova possibilidade expressiva favorecida pela tecnologia da escrita on line, a proposta deste estudo consiste em responder quais os mecanismos são mais produtivos em relação ao que vem acarretando expressivas ocorrências de palavras novas (expressões, termos novos) em textos veiculados em redes sociais? Pretende-se estudar os empréstimos e as gírias de origem inglesa? Desta forma se avança a hipótese de que os usuários das redes recorrem ao inglês devido ao fato de que esta língua tem mais prestígio em nível internacional e os usuários usam expressões próprias do seu grupo de amigos que de certa forma fogem à norma-padrão. Outra hipótese é a de que os membros de redes não respeitam as regras da escrita da língua portuguesa.

Deste modo, este estudo tem como objetivos discutir os conceitos de léxico, lexicologia, neologismo (por empréstimo), buscando, de alguma forma traçar também a história desses termos no decorrer dos estudos linguísticos; identificar as características linguísticas dos usuários das redes sociais em particular do Facebook; explicar as formas como os discursos são construídos nessas redes e apontar as expressões e termos. Propõe, ainda, direcionar o estudo para o âmbito dos estudos lexicais, com incursões em processos de ampliação do léxico, especificamente no que concerne à criatividade de falantes em usar ou 
mesclar seus textos com palavras e expressões da língua inglesa criando variadas expressões que atingem não apenas o léxico, mas outros níveis gramaticais: fonética, morfologia, sintaxe e pragmática.

A metodologia consiste inicialmente no levantamento de estado da arte utilizando uma abordagem qualitativa para recolha e análise dos dados. Serão objetos de análise postagens de usuários do Facebook, sendo 7 homens e 13 mulheres, no período de março a outubro de 2016. Todos os usuários são brasileiros residentes na cidade de Morrinhos, Estado de Goiás.

$\mathrm{O}$ artigo se divide em 4 seções. Na primeira parte discutiu-se os conceitos relativos ao léxico e a lexicologia colocando em debates vários estudos e contextualizações acerca dos temas. Na segunda seção discutiu-se sobre os empréstimos e sobre como um fenômeno neológico se manifesta na linguagem, apresentando alguns autores que discutem com propriedade esses fenômenos que acontecem na neologia. Já na terceira viu-se como os empréstimos podem ser necessários ou de luxo culminando com a apresentação da metodologia de recolha e análise de dados recolhidos dos corpora. O artigo termina com apresentação de conclusões e de referências.

\section{0 léxico e a lexicologia: estudos e conceitualização}

O estudo sobre o léxico é complexo e exige um conjunto de conhecimentos teóricos muito profundos. O léxico está em nível do sistema, se considerarmos a tricotomia de Coseriu: sistema, norma e fala. Já que a língua é abstrata e só se manifesta na fala seguindo uma norma concebida pela comunidade linguística. O léxico reflete as palavras usadas numa determinada língua. Correia (2011, p.227) define o léxico como "o conjunto virtual de todas as palavras de uma língua, isto é, o conjunto de todas as palavras da língua, as que são possíveis tendo em conta as regras e os processos de construção de palavras."

De forma mais concreta, o léxico seria o acervo de palavras utilizadas pelos falantes da Comunidade de Países de Língua Portuguesa (CPLP). Por isso, o léxico é tão amplo que nem o dicionário consegue dar conta dele, pois ademais de sua amplitude, está em constante remodelação e reconstrução. Para Biderman (2001, 1981), o léxico pode ser entendido como o conjunto de todas as palavras de uma língua, ou melhor, é o vocabulário dessa. No léxico de qualquer língua podem ser incluídas unidades diversas e heterogêneas, sejam monossílabos e vocábulos simples até expressões bastante complexas do ponto de vista de sua formação (composição), assim como, sequências formadas por vários vocábulos, inclusive frases inteiras, como, por exemplo, as expressões idiomáticas e os provérbios. 
Na verdade, o homem tende a nomear tudo que faz parte de seu universo, classificando e dando significado a tudo que o cerca. Conforme Biderman (1996), toda realidade circundante possui um nome, inclusive as próprias pessoas. Aliás, uma das primeiras ações em relação a um recém-nascido é a escolha de um nome. Nomear é conhecer e o léxico associa-se ao conhecimento e a qualquer processo de denominação (seja de objetos ou de novos comportamentos), o léxico é o resultado de operações perceptivo cognitivas. Para Biderman (1996), o léxico é o locus do conhecimento sob o rótulo de palavras.

As palavras são associadas aos conceitos que dão sentido ao mundo, nomeando as coisas e formando o universo referencial que se tem dentro de uma língua. Cabe salientar que tudo isso é permeado pela visão de cada povo. De acordo com Sapir (1969), ao captar e registrar aspectos extralinguísticos que se circunscrevem ao ato de nomeação da realidade, o falante faz com que exerçam figurativamente a função de refletores de características físicas e culturais do ser nomeado, retratando a interinfluência entre homem, língua e cultura.

Nesse sentido, Sapir (1969) também observa que, em relação ao léxico mais específico, é necessário enfatizar que não é a topografia e a fauna da região em si mesma, que a língua recorta e reflete, mas sim o interesse do grupo por tais entidades. O léxico dá forma e conteúdo ao mundo, à realidade, o que permite compor a memória individual e coletiva. Cabe salientar que, compreender o léxico de uma língua pode ser um tanto complexo, pois as palavras são associadas a conceitos próprios de cada cultura, atribuídos pelos falantes e, como qualquer bem cultural, é legado de geração a geração, mas não de forma estática, estão em constantemente variação e mudança.

Para Greimas (apud NEBOT, 2003, p. 121), "o léxico se constitui em um espelho da vida. Espelho da vida [...] tanto material como intelectual e espiritual ${ }^{3}$,, e Rohlfs (apud NEBOT, 2003, p. 121, tradução nossa) ainda enfatiza que "é claro que as relações entre língua e cultura são mais evidentes e visíveis no domínio da cultura material, como se fazem mais vagas e indiscriminadas conforme nos aproximamos da cultura espiritual"4.

Outro fato que merece atenção é que não há como registrar 'todas', quer dizer, não se pode encontrar corpora mais generalizado que possa dar conta do léxico. O fato neológico, não se encontra dicionarizado. Aliás, esse é um critério para se determinar que um lexema é ou não é neologismo. São essas expressões que constituem o objeto de estudo desta pesquisa.

\footnotetext{
${ }^{3}$ el léxico se constituye [...] en un espejo de la vida. Espejo de la vida [...] tanto material como intelectual y espiritual. (NEBOT, 2003, p. 121).

${ }^{4}$ Es claro que las relaciones entre lengua y cultura son más evidentes y visibles en el domínio de la cultura material, en tanto se hacen más vagas e indiscriminadas conforme nos acercamos a la cultura espiritual (NEBOT, 2003, p. 121).
} 
Dessa forma, um estudo lexical pode focar em palavras já existentes na língua ou em palavras novas ainda não dicionarizadas.

Dentro do léxico, pode-se identificar o léxico geral (aquele que corresponde ao conjunto de palavras compreensíveis e usadas por toda a comunidade linguística) e léxico específico (aquele conjunto de palavras que ocorre numa determinada variedade (TIMBANE, 2014a). Com o advento da tecnologia, das redes sociais e da televisão a cabo e outras formas de comunicação globalizadas o léxico específico tende a passar para o geral o mais rápido. As palavras ônibus (substantivo), jóia (adjetivo), galera (substantivo) só ocorriam exclusivamente no português do Brasil, mas hoje se expandem e chegam na lusofonia através das novelas e outros meios. As palavras kota (velho), kumbu (dinheiro), camba (amigo), bazar (ir embora) são do português de Angola. Mas estas unidades lexicais se expandem rapidamente para Moçambique, Guiné-Bissau, Cabo Verde e Portugal através da música. Isso acontece porque "as línguas refletem nos seus léxicos o espaço onde são faladas e o momento histórico em que são utilizadas como meio de comunicação e expressão" (PETTER, 2008, p.61).

A ciência que se dedica à organização ou ordenação das palavras que compõem o léxico de uma língua é a Lexicografia. A Lexicologia, para Camacho (2008), é o estudo da organização do léxico dentro da língua e cabe a ela, as análises do léxico. Por seu caráter pluridisciplinar, o léxico pode ser estudado vinculado aos aspectos históricos, geográficos, culturais, sociais, tecnplógicos entre outros.

Segundo Welker (2004), a lexicografia é a atividade de elaboração de dicionários. A lexicografia é uma disciplina indissociável da lexicologia, já que estas estão intimamente ligadas pelos laços do léxico. Cabe à Lexicografia, porém, a atividade de catalogar e descrever o léxico a fim de produzir dicionários, tanto impressos quanto eletrônicos, estes podem conter todos os tipos de itens lexicais ou tipos específicos, podem ainda ser bilíngues, trilíngues ou multilíngues. É possível ainda ressaltar que o intuito dos estudos da Lexicografia é o trabalho sobre corpora que descreve de maneira eficaz o uso do léxico.

Para Nebot (2001, p. 17), ambas as palavras (Lexicografia e Lexicologia) aparecem no “diccionario de la lengua castellana”, de P. Esteban Terreros, em 1734, com definições que as distingue nos seguintes termos: Lexicografia "arte de la ordenación de um Diccionario" e Lexicologia definida como "el tratado de la voz, ó palavra em particular; por su voz em particular". Para Terreros (apud Nebot, 2001), lexicologia é a palavra do homem, é o som articulado que significa, que denota, que remete a, pelo menos, um significado.

Nebot (2001) traça o caminho desses dois termos através do desenvolvimento da linguística como ciência, ilustrando com citações de vários autores a visão de cada corrente de 
pensamento em relação ao estudo do léxico. De acordo com Nebot a Lexicologia é a ciência que trata do conhecimento fundamental das palavras, considerando sua relação com o valor, etimologia e também tudo o que for indispensável para aprofundar para compor o léxico. $\mathrm{O}$ autor ainda acrescenta várias definições de Lexicologia que constam nos dicionários espanhol desde a primeira ocorrência à abordagens mais atualizadas dos termos.

A lexicologia também é considerada uma ciência que tem como objeto o conhecimento das vozes (palavras), consideradas sob o ponto de vista de seu valor, etimologia e tudo que necessita para compor o léxico (GASPAR e ROIG apud NEBOT, 2001). Como se vê, as definições evidenciam a questão da significação como âmbito do estudo da Lexicologia, ressaltando para tanto a busca das diversas acepções que uma palavra pode ter (ou conter). Isso apenas mostra que antes do aparecimento da Semântica em 1954, questões de valor, etimologia, significação e, posteriormente, referência estavam a cargo exclusivamente da Lexicologia, como parte da gramática que se atinha ao estudo de vários aspectos das palavras, inclusive a observação da formação de palavras (BARBOSA, 1981). Nesse sentido, pode-se incluir a criação ou aparecimento de palavras novas, tratadas como fenômenos neológicos ou neologismos.

Segundo Crystal (2005), essa ocorrência é apenas um ciclo natural que toda língua está sujeita em sua existência, pois nenhuma língua vive de forma isolada, todas mantêm algum tipo de contato umas com as outras. Isso faz com que se influenciem mutuamente. As de maior alcance tidas como principais línguas internacionais, como o português, o espanhol e o francês, exercem mais influência sobre suas línguas de contato. E o inglês, como língua global, por natureza, exerce mais influências que todas as outras.

Os povos estão em contato e isso favorece inúmeras trocas e interinfluências sociolinguísticas ou culturais. Em um mundo globalizado e de crescente inovação tecnológica, e é natural que haja intenso contato entre as diferentes culturas, acentuando também diversos processos de influência mútua, contribuições na forma de empréstimos culturais ou linguísticos. Toda língua, em determinado momento, recebe contribuições que são os empréstimos de outras línguas.

Na perspectiva de Alves (2004), a língua inglesa mais do que qualquer outra, tem emprestado itens lexicais à língua portuguesa, principalmente nos campos técnico e científico. As modernas tecnologias e as redes sociais vêm aproximando as pessoas de uma forma virtual, mas possibilitando que haja empréstimos entre as línguas de modo a designar também comportamentos que surgiram ou se modificaram em função dessas novas maneiras de interagir pela linguagem. 
De acordo com Assis (2007), não é difícil observar a contribuição do inglês para criação de novas expressões no português brasileiro em vários espaços, como por exemplo, nas propagandas escritas e faladas, na televisão, nos nomes e embalagens de produtos, na área de marketing e propaganda, na internet, enfim em inovações da tecnologia. A guisa de exemplo, podem ser mencionadas as palavras joint venture, franchising, leasing, light, diet entre tantas outras. Esses empréstimos "entram” na língua, integrando-se de alguma forma o vocabulário de algum estrato linguístico, sendo que o falante modifica, aportuguesando-as fonológico, morfológico e semanticamente na língua portuguesa.

Importante ressaltar que toda mudança que ocorre na língua forma um paralelo com as mudanças humanas, com as mudanças no comportamento social das pessoas, ou melhor, correspondem às necessidades de grupos específicos ou não de falantes durante a manifestação criativa, cuja população possui um mesmo sentimento de inovação, criação ou adoção.

Para Carvalho (2009), toda língua é dinâmica e que suas manifestações podem provocar mudanças sociais, integrando novas formas, novas as necessidades expressivas que se renovam. Também a língua, dado seu caráter dinâmico, não é um produto acabado e pronto, ela vai variar e se refazer continuamente. Na maioria das situações de interação entre povos de culturas diferentes, pode-se perceber fortemente pela demanda de termos de origem inglesa sobre as demais línguas do mundo, uma vez que o inglês alcançou status jamais visto em nenhuma outra língua nas últimas décadas.

\section{Os empréstimos como fenômenos Neológicos}

Embora os estudos sobre os empréstimos possam ser tratados pelos estudos de morfologia lexical, de formação de palavras, acolhe-se para este estudo, bases teóricas da Lexicologia por entender que os neologismos, de certa forma, também podem ser estudados do ponto de vista lexicológico em correlação com fenômenos de base morfológica. Conforme Bueno (1994, p. 401), o significado da palavra "empréstimo" equivale ao "ato de emprestar, de tomar emprestado." Como fenômeno linguístico, pode ser entendido como um fator de aquisição e de provisão entre as línguas, que, de certa forma e em algum grau, sofrem influências pelo contato entre os falantes de diferentes classes sociais, regiões ou país.

Para Carvalho (2009, p. 54), “os empréstimos pressupõem uma interpretação, uma adaptação à estrutura da língua importadora.” Nessa perspectiva, o empréstimo caracteriza-se como um aspecto inerente às línguas, que faz parte e está diretamente relacionada às 
mudanças linguísticas, impulsionando-as. Segundo Carvalho (2009), as mudanças linguísticas ocorrem devido à própria natureza da língua, e os empréstimos são parte dessas mudanças.

Carvalho (2009) ressalta que o empréstimo é resultado ou consequência do contato (direto ou indireto) entre as línguas. Quando o termo emprestado atinge grande popularidade, quase sempre, é adaptado para uso na forma normalizada da língua. Sua disseminação é caracterizada, por isso, pela força da comunicação empregada pela população. Os empréstimos contribuem para que mudanças ocorram, eles advêm então dessa perspectiva de adoção que está inteiramente ligada às relações humanas. À medida que, a sociedade passa por mudanças de costumes e crenças, mudam também seus valores, suas necessidades e seus objetivos, contribuindo, assim, para a alteração das necessidades comunicativas durante a interlocução.

Já em Grosjean (1982), encontra-se o conceito de empréstimo como o uso de uma palavra de outra língua que é adaptada à língua base. O estudioso indica como fator predominante para a adoção de empréstimos a inexistência de itens lexicais em determinada língua para a expressão de novos conceitos, objetos e lugares em função da necessidade de ampliação vocabular, dadas as novas experiências socioculturais e a necessidade de comunicação decorrente delas.

Bloomfield (apud CARVALHO, 2009) classifica os empréstimos considerando a origem: em íntimos, culturais e dialetais. Os três correspondem ao tipo de adoção lexical. O empréstimo íntimo ocorre mediante a convivência de duas línguas no mesmo território; o empréstimo cultural ou externo é o tipo mais frequente, pode ser definido por contatos políticos, sociais, comerciais e militares entre os povos, sempre combinado pela dominação de algum deles, consiste no empréstimo por influências culturais; o empréstimo dialetal é o que acontece entre falares da mesma língua, por meio de variantes regionais, sociais e jargões especializados. Carvalho (2009) entende que esses modos são em sua maioria, de natureza lexical, ou seja, são responsáveis pela renovação vocabular.

Pode-se ainda mencionar o empréstimo não-lexical, cuja ocorrência é mais incomum. A adoção de fonemas, por exemplo, quase não acontece, visto que, os falantes, quase sempre, alteram o termo lexical emprestado de acordo com os fonemas da língua, ou melhor, quase tudo que entra via empréstimo, inevitavelmente passa pelo filtro fonético-fonológico do português.

Para Carvalho (2009), os empréstimos podem ainda ser classificados como denotativos ou conotativos. Os primeiros abarcam os itens de função referencial, que incorporam um objeto ou conceito novo por intermédio de domínio cultural e podem ser 
associados aos termos que acompanham o objeto ou conhecimentos importados. Os conotativos são de caráter estilístico da fala, com função expressiva, caracterizados por deferência à cultura do outro. Os denotativos referem-se aos que Grosjean (1982) denomina de “necessários” e os conotativos aos “desnecessários”, já relacionados acima.

\section{Os empréstimos "necessários" e "de luxo" na perspectiva de Timbane (2013)}

As línguas em geral nunca estiveram livres da ação de fatores extralinguísticos ou até mesmo de fatos linguísticos inerentes a elas. Não há nenhum mecanismo capaz de conservar e proteger as línguas de influências ${ }^{5}$ que, para os mais normativistas, corrompem as estruturas e estabilidade das línguas. Pelo contrário, as línguas dispõem de mecanismos de formação de palavras que quando esgotados requerem a necessidade de emprestar termos de outras línguas.

O vocabulário do falante é atualizado continuamente, com tamanha influência das tecnologias, cada vez mais falantes buscam novos termos, importados juntamente com as tecnologias, constituindo matéria-prima para construção e atualização de seus vocabulários. Pode-se observar ainda, que com o advento das redes sociais, a propagação destas novas expressões é mais rápida e acentuada, pois atinge um número grande de pessoas independente da região do país.

Para Crystal (2005), a importância da questão é vasta já que traz consequências de uma tendência globalizante em que forças de mercado e forças culturais foram liberadas, erodindo pontualmente o equilíbrio do poder linguístico. São, na verdade, forças opostas que agem, por um lado, a invasão das línguas dominantes num determinado espaço geográfico, por outro, a manutenção e desenvolvimento da diversidade linguística.

As palavras vindas de outras línguas podem ser "necessárias", mas também podem vir por motivações mais secundárias, quer dizer de "luxo". Segundo Timbane (2013), um empréstimo necessário é aquele que não tem equivalente na língua de chegada. Existem realidades próprias de um contexto social e cultural que não possuem equivalência. Deste modo, pode-se buscar a palavra da língua estrangeira para completar essa falta/lacuna existente na língua.

Antes dos exemplos, precisa-se deixar claro que a língua portuguesa não é falada/escrita da mesma forma na lusofonia. Portanto, cada variedade tem um conjunto lexical e semântico próprio que caracteriza a sua variedade. Desta forma,

\footnotetext{
${ }^{5}$ Nem o projeto de Lei 1676, Dispõe sobre a promoção, a proteção, a defesa e o uso da Língua Portuguesa e dá outras providências e é da autoria do Deputado Aldo Rebelo.
} 
os falantes se socorrem da sua língua materna para completar lacunas. nqueka: é um pequeno pano cortado de lençol que as mulheres amarram na cintura nas primeiras duas semanas após o parto. Provém da língua xichangana; catchiza é um tipo de batuque característico da província de Nampula; malassas: fruto silvestre com casca dura, de polpa doce e sementes grandes e duras (a planta nasce nas savanas africanas); muravarava: jogo tradicional; mapiko é um tipo de dança; uputsu: bebida feita de farinha de milho literatura (TIMBANE, 2013, p.255).

Os exemplos citados por Timbane (2013) mostram como o léxico é dinâmico e ativo a todo o momento. Essas realidades mostradas nas comunicações dos moçambicanismos não ocorrem nas de outros lusófonos, pois refletem uma realidade própria desses. Por outro lado, os empréstimos de luxo seriam aquelas palavras que têm seu equivalente na língua portuguesa, como, por exemplo, show, fashion, deletar, game, enter, brother e drink. Correspondem a espetáculo, moda, apagar, jogo, entrar, irmão e bebida respectivamente. A escolha das palavras inglesas se justifica pelo prestígio que o inglês tem em nível internacional.

Os falantes preferem as palavras inglesas por questões de luxo apenas, de mostrar um status que eles ocupam na sociedade. Entram na língua por meio de cidadãos que falam a língua inglesa, acabando por se aportuguesar e integrando-se na nossa língua. Hoje, as palavras jeans, shopping, game, aids e muitas outras, já não são do inglês. São da língua portuguesa. Foram adotadas, dicionarizadas e autenticadas como parte integrante do acervo lexical do português. Portanto, pode-se dizer que essas palavras são da língua portuguesa, mas de origem inglesa. A integração total da palavra ocorre quando os falantes já se esquecem da origem da palavra. Por exemplo, parece que esquecemos que "gol" significa "objetivo" e ninguém grita "objetivooooooo" quando a bola ultrapassa a linha entre as duas balizas numa partida de futebol.

Estes aspetos todos ganham força porque língua é cultura nas suas vertentes. Daí que se discute a lexicultura, conceito discutido com profundidade por Timbane (2014). A palavra lexicultura provém da junção das palavras "léxico" e "cultura". Entendemos por "cultura" como o conjunto de padrões de comportamento, de conhecimento, de crença, da arte, da moral, da lei, dos costumes e de todos os outros hábitos e capacidades adquiridas pelo homem como membro da sociedade. Sendo assim, a cultura carrega consigo as suas especificidades, por isso que se pode notar a existência de significados e sentidos semânticos diferentes de uma comunidade linguística para outra. 
Seria importante compreendermos que a língua só faz sentido dentro do contexto social. As palavras ganham sentidos pragmáticos mais profundos dentro do uso numa comunidade linguística. A lexicultura, segundo Timbane (2014a) se divide em dois tipos: a geral e a específica. A primeira é aquela que agrupa itens lexicais que são identificados por toda comunidade linguística, quer dizer, a lexicultura ao nível macro, enquanto que a segunda abrange "o conjunto de itens lexicais que caracterizam uma variedade ou variante específica, ou seja, pertence a um grupo restrito.” (TIMBANE, 2014a, p.47).

A internet é um mundo gigantesco a ser explorado. Para Rajagopalan (2013, p.50),

o advento da internet e a consequente mudança de velocidade, volume e formas de comunicação em massa, desembocando no uso de múltiplas formas de mistura de gêneros e recursos semióticos, vieram a sanar definitivamente qualquer dúvida remanescente a esse respeito.

A internet existe e sempre existirá. O que os linguistas podem fazer é investigar, estudar, entender e/ou compreender o fenômeno internet na vida da comunidade linguística, pois o fenômeno está influenciando na variação e na mudança da norma-padrão. Para Sardinha (2013),

os usuários de registro como email, twitter, facebook, webpages e blogs tomam emprestada a linguagem de outros registros para essas novas formas de comunicação. Nesse processo de adaptação, esses registros da internet passam a ter perfis linguísticos distintos, mas não exatamente singulares ou exclusivos (SARDINHA, 2013, p.74).

O que é importante a observar na internetês é que a norma-padrão não é observada. Os usuários não se importam em fazer abreviaturas, siglas e acrônimos para além de reduzir frases. Naquele espaço virtual, os interlocutores se entendem, principalmente quando compartilham os mesmos ambientes de diversão ou de outros interesses. A seguir, veremos os caminhos que foram trilhados para a coleta e análise dos dados.

Terminamos esta parte esclarecendo que a língua falada é diferente da escrita. A escrita é artificial, depende do acordo ortográfico e da norma-padrão. Isso tudo é aprendido e não adquirido tal como a acontece com a língua oral. A língua oral se processa através da aquisição e ocorre no meio social (familiar) sem metodologia, objetivos pré-estabelecidos e avaliação sistemática. Quando se observa que as redes sociais mexem com a língua falada e escrita há uma curiosidade por parte dos pesquisadores em compreender como isso se processo e como as duas formas distintas interagem.

\section{Metodologia, análises e discussão dos dados}


Para o levantamento de dados, se empregou a técnica da recolha direta em algumas páginas de relacionamentos do Facebook, observando os fenômenos linguísticos presentes nas postagens que os jovens e adultos fazem diariamente. Serviram de objeto de análises desses fenômenos linguísticos 20 internautas, sendo 7 homens e 13 mulheres, todos residentes no Estado de Goiás, na cidade de Morrinhos e possuem o português como língua materna.

A escolha dos internautas foi dividida em 3 grupos: nível superior, nível médio e nível fundamental. A divisão pelos grupos objetiva analisar quais grupos apresentam empréstimos e quais as características dessas mensagens. As análises abrangem o período março a junho de 2016. Os nomes dos indivíduos que fizeram parte da pesquisa foram protegidos e os seus nomes verdadeiros foram substituídos por nomes fictícios, pois o que interessa são os dados e não a identidade dos sujeitos.

É comum o uso de palavras e expressões que até o momento não existiam e começaram a existir simplesmente pelo fato de possibilitar o ato da comunicação. $\mathrm{O}$ acesso diário aos blogs possibilita investigar a interação entre os membros do grupo e, consequentemente, a ocorrência de neologismos. Espera-se que com os resultados da investigação seja possível verificar a ocorrência de empréstimos que estão na base da formação de novas palavras na nossa língua.

Observando nos exemplos 1, 2 e 3 observa-se a chegada das palavras inglesas top, play, best, friend e a palavra francesa tour.

Ex. 1: "Tomando em casa com amigos tudo de bom top." (Mário)

Ex. 2: "\#play \#feriadao...Depois.. E depois heheheheh. Best friend!” (Jane)

Ex. 3: "Tour em Paris... \#Sqn\#FeriadoComAsAmigas.” (Virgínia)

Nestes três exemplos observa-se que os interlocutores usaram as línguas portuguesa, francesa e inglesa. Um fato que chama bastante atenção é que muitas das vezes, existem palavras que têm correspondência ao mesmo significado na língua materna do interlocutor, mas sentem a necessidade de usar tais estrangeirismos. Por exemplo:

Ex. 4: “...Gente vídeo top! ” (Antônio)

Ex. 5: “...Só pq hj é seu dia vou aceitar postar esta foto que ... E esse body mais lindo e delicado do mundo..." (Joana)

Ex. 6: "...Obrigada baby da Mamãe por me reerguer a cada minuto e confie nos meus cuidados pois nunca lhe faltará!!!!” (Maria)

No exemplo 4, observa-se que a palavra top poderiam ser substituída pelo adjetivo 'bom', mas o autor preferiu utilizar uma palavra estrangeira. No exemplo 5 vê-se como a palavra vinda do inglês mudou o seu valor semântico. No inglês, body é 'corpo', mas ao ser 
aportuguesa teve o seu sentido alterado, passando a ser 'tipo de roupa feminina'. Esse é um estrangeirismo que, além de ser estrangeiro, perdeu, consequentemente, o sentido original. $\mathrm{O}$ mesmo aconteceu com a palavra baby (Ex. 6), no qual a palavra inglesa perdeu os seus valores semânticos iniciais relativos a 'bebê', passando a significar 'queridinho'. Este processo de escolha de palavras estrangeiras que possuem significados equivalente em português são designados de empréstimos de luxo, pois a sua vinda se justifica pelo capricho, pelo estilo.

Nas postagens, verificou-se que a maioria dos empréstimos utilizados foi de origem inglesa e nos textos selecionados foram identificadas palavras como: top, tour, play, hello, Sunday, day, body, phyna e entre outras. Sendo empregada apenas uma palavra de origem espanhola nas 20 postagens analisadas, por um indivíduo, do sexo masculino, da faixa etária entre 18 a 25 anos de nível escolaridade ensino fundamental:

\section{Ex.7: “... Eu To De Buenas ...” (Dante)}

Dante ao proferir que "estava de BUENAS", valeu-se de uma expressão que significasse estar bem ou, em outras palavras, que estava se sentindo bem, já que a tradução desta palavra significa BOM. Observa-se que o sujeito em analise mesclou o espanhol com o português para dar ênfase ao seu estado, para que as pessoas entendessem que ele estava bem e tranquilo, como pode ser evidenciado pela pose em que ele se encontra na foto que acompanhava a frase.

Outro fenômeno observável diz respeito às várias vezes em que houve modificação de palavras, surgindo trocadilhos, como, por exemplo, a utilizaçãoda letra 'U', quando o uso correto, de acordo com a ortografia Brasileira, seria a utilização da letra 'O'. Entende-se este fenômeno como a oralização da escrita. Os exemplos 8, 9 e 10 são representativos deste fenômeno:

Ex. 8: "... Quero agradecer minhas amigas de serviço pelo carinho que tem por mim adoro vcs equipe maravilhosa. brigaduuu..." (Helena)

Ex. 9: “... Com os zamigos.... noite maravilhosa com César e Bruno!...” (Fátima)

Ex.10: "Com as amigas...., que um dos indivíduos da analise utilizou a seguinte escrita: 'CAZAMIGAS', a palavra 'SAUDADE', andam escrevendo por ai SDDS.'(Helena)

No domínio da ortografia são úteis noções como as de relação som-grafia (plano fónico e plano escrito de representação da língua), fonética articulatória e classificação dos sons para a resolução de erros fonéticos. Mas o que acontece nestes casos é que os internautas não se importam pela grafia correta, mas sim pela mensagem. Fato que acontece com a 
palavra 'OBRIGADO', que em diversas postagens se tornou 'BRIGADUUU', tal como se pode ver no exemplo 10. Observa-se que o indivíduo que se referiu à palavra BRIGADU (Ex.8), pertence ao grupo de indivíduos que possuem o Ensino Médio. Isso significa que não comete erro por não saber, mas sim pelo relaxamento, pois o indivíduo sabe que não será cobrada a escrita correta naquele contexto. Já no Ex. 9 a expressão COMAZAMIGAS passou a ser uma única palavra. O indivíduo que escreveu possui o ensino superior completo.

Tanto os indivíduos mais escolarizados quanto os menos escolarizados constroem frases ortograficamente erradas no Facebook, não pelo fato de não conhecer a escrita, mas sim pelo fato do meio usado (internet/redes sociais) permitir e dar essa liberdade. Entende-se ainda que a ocorrência de estrangeirismos no Facebook não está relacionada com a formação acadêmica, mas sim pelo contato com as redes sociais. Isso significa que quanto mais o indivíduo lida com a internet, mais possibilidades têm de integrar com estrangeirismos, independentemente da formação acadêmica. Por isso que há vários casos de internautas com nível superior que cometem erros grosseiros. Considera-se que não se trata de erros, uma vez que os internautas estão cientes do desvio à norma da escrita. Trata-se de uma grafia/escrita específica das redes sociais.

Ainda na análise das postagens foi possível observar várias maneiras de demonstrarem que estavam sorrindo, enquanto alguns utilizam RSRSRSRS, outros KKKKKKKKKK e outros HEHEHEHEHEHEHE. Diante da diversidade de formas, não há como definir qual seria a grafia correta de representar risadas e gargalhadas.

Ex. 11: “...Início das comemorações.. Hj, amanhã.. Depois.. E depois heheheheh. Best friend..." (Anália)

Ex. 12: “...Mas é bom lembrar que a vida de todos nós é permeada por dias tristes, sem maquiagem, sem esmalte, chatos, com problemas ... Senão a gente começa a pirar achando que todo mundo é lindo e feliz como nas redes sociais ... RS. Né ... kkkkkk...” (Madalena)

Os Ex.11 e 12 são apenas alguns exemplos de muitas formas de exprimir sentimentos. Para além dessas representações de emoções existem 'moções' que também trazem o mesmo significado. Em muitas línguas, existem outras formas de representar o riso, o que reforça a ideia de que língua é ao mesmo tempo cultura.

Convém ressaltar que a criação de palavras por empréstimos atualmente traz consigo uma gama infindável de questões que perpassam, de alguma maneira, outras tantas questões de ordem social, política, linguísticae cultural. É essa perspectiva de análise que se pretende obter com este estudo de neologismos tais como: zueira never end, bater a bad, crush (Ser crush de alguém/ter crush) e outros ainda a ser coletados. O uso de letras maiúsculas chama atenção ao 
leitor, mas não se entende nos corpora recolhidos se o uso das maiúsculas é intencional ou por acaso. A mudança do formato da letra pode ser vista como uma forma de dar realce e enfatizar o que se tem a dizer como se pode ver no exemplo a seguir:

Ex.13: TE AMO PARA TODO O SEMPRE. Obrigada aos meus pais por tanto apoio e amor (Anália)

Outro aspecto a observar nos dados da pesquisa é que os jovens são os que mais escrevem no Facebook, postando todas as informações do dia a dia no Facebook, indo além de fotos e vídeos que relatam o dia a dia. Geralmente, as fotos passam mais informações do que o texto escrito, uma vez que a fotografia é suscetível de várias interpretações ao considerar-se a cultura e a experiência do leitor.

As gírias produzidas pelos jovens internautas de hoje podem ser as palavras a serem utilizadas na nossa língua amanhã. Tudo dependerá da frequência e da necessidade do uso. $\mathrm{O}$ que nos anos 80 se chamava de bocomoco (cafona), nos dias de hoje se chama brega. O que se chamava pão (cara bonito há décadas atrás) hoje se chama gato ou top. Esses exemplos ilustram como a dinâmica vai variando segundo os contextos sociais e até econômicos e tecnológicos em que os falantes estão inseridos. As redes sociais são, na verdade, verdadeiros espaços de comunicação e de interação que promovem a expansão de novas palavras.

Uma análise rápida sobre as postagens dos usuários do Facebook em Moçambique e no Brasil, permitem compreender como as palavras (palavras do português e empréstimos) são diferentes. Isso mostra como a língua é social e só faz sentido. Em Moçambique, observase a presença de empréstimos vindos principalmente das línguas bantu moçambicanas ao invés do inglês, em que cada variedade reflete a cultura e as intenções do povo.

\section{Conclusão}

Este artigo objetivou revisar alguns conceitos referentes aos estudos dos empréstimos enquanto fenômenos neológicos, tratados como lexia de ocorrência nova, principalmente em Redes Sociais, com base em Alves (1996), Citelli (2006) ou Steinberg (2003) entre outros, uma vez que o fato neológico pode ser interpretado de diferentes maneiras e sob aportes teóricos variados. Nesse sentido, buscou-se rever conceitos que possam de alguma maneira, elucidar alguns processos sincrônicos que estão na base da formação de palavras no português brasileiro.

Nessa perspectiva, o desenvolvimento do estudo vem possibilitando a identificação de ocorrências desses neologismos, ou seja, de expressões neológicas advindas de empréstimos 
que a comunidade mais jovem da internet vem fazendo através da língua inglesa. $\mathrm{O}$ estudo vem suscitando também questões de análise dos processos neológicos já que foram verificados em alguns dados, combinações de elementos de ambas as línguas (português e inglês), a princípio, bastante inusitadas. Semasiologia entendida como estudo de mudança de sentido que favorece várias aplicações referenciais e acepções para as palavras, o que se situa diante de análises do movimento semântico ou câmbio semântico, que, em muitas situações, criam neologismos semânticos.

Desta pesquisa concluiu-se que os usuários das redes recorrem ao inglês devido ao fato desta língua ter mais prestígio internacionalmente; como também se utilizam de expressões próprias do seu grupo de amigos e que, de certa forma, fogem à norma-padrão. Outra hipótese é a de que os membros das redes não respeitam as regras da escrita da língua portuguesa.

Os indivíduos observados utilizam o Facebook para conversas do dia a dia e de maneira informal criam neologismos, isto é, inventam, criam ou trazem emprestadas palavras de outras línguas, seja por "necessidade" oupor "luxo". Destaca-se ainda que há a predominância de léxicos de origem inglesa, como também o fenômeno da mescla de dois idiomas, ou seja, começam com o português e de repente em alguns momentos utilizam palavras inglesas.

Ao longo deste artigo, concluímos que nos dias atuais as redes sociais são consideradas um dos meios mais fáceis das pessoas se relacionarem entre si e fazerem novas amizades. Elas veem cada vez mais facilitando a vida dos usuários, desde o seu surgimento aos dias atuais. Nelas podemos conversar tranquilamente com pessoas do mundo todo, postar imagens e vídeos que em apenas um click podem ser vistas pelo mundo inteiro aoterem acesso as nossas informações.

Nessa perspectiva, pode-se afirmar que o léxico e a cultura, são parceiros fidelíssimos no processo de comunicação, uma vez que ambos estão ligados à identidade do sujeito, já que cada indivíduo tem liberdade para proferir quaisquer palavras de acordo com as situações de comunicação ou ainda, de acordo com os contextos em que acontece o discurso. Essa tendência foi evidenciada durante o presente estudo feito nas redes sociais, pois ambos caminham um ao lado do outro. Muitos significados só podem ser interpretados entre indivíduos de uma mesma comunidade, como, por exemplo, a ideia que se tem de adulto na cultura europeia é diferente da ideia que se têm nas tradições da etnia macua, localizada geograficamente ao norte de Moçambique. Enquanto entre os macuas, adulto é aquele que frequentou e aprovou nos ritos de iniciação, nas tradições europeias adulto seria aquele que 
possui dezoito ou mais anos. $\mathrm{O}$ entendimento e a interpretação do mundo depende muitas vezes dos valores culturais atribuídos pela comunidade linguística, pela cultura e pelas tradições.

Nas postagens feitas pelos usuários do Facebook foi possível observar que existindo ou não palavras adequadas para designar tal situação, os indivíduos jamais deixam de se comunicar caso não exista palavras correspondentes. Os mesmos criam, inventame buscam estrangeirismos (necessários ou de luxo) para que possam alcançar seus objetivos comunicativos. O fenômeno neológico contribui significativamente com essa nova era da sociedade da informação e da comunicação, visto que a todo momento, os indivíduos que se utilizam das redes sociais estão criando novas palavras, novos nomes e assim vivendo e comunicando-se tranquilamente nesse novo mundo da informação e do conhecimento.

Os resultados das análises mostram claramente que o recurso aos empréstimos ocorre na língua inglesa e não no espanhol, embora esta última fosse uma língua importante no espaço da política linguística. O recurso ao inglês denúncia a importância desta língua no espaço internacional. Entendamos esse evento como um destino normal de todas as línguas. Ninguém mais se lembra que as palavras futebol, basquetebol, shopping, radar, short, chip, CD, HIV, RAP, DNA vieram do inglês. Fenômenos como os que ocorrem no Facebook vão se consolidar num curto ou talvez longo período de tempo e não serão mais sentidas como palavras estrangeiras.

Os dados mostraram que há uma renovação lexical das redes sociais causada pelo uso de termos estrangeiros, como nos exemplos: chavoso ou massa (para se referir algo que é bom, legal), bug (algo que está com defeito), crush (estar a fim de uma pessoa; paquerar), trollar (aprontar algo com alguém; zoar; fazer uma brincadeira), flop (algo que dá errado), nude (envio de foto/video com pessoa nú), selfie (autoretrato), views (visualizações).

Observou-se que os jovens são os que mais criam palavras e expressões que, inicialmente surgem como gírias. O fenômeno neológico é normal em todas as línguas em uso no mundo. Sendo assim, é necessário observar que este fenômeno não ocorre de forma desorganizada e aleatória. O processo de criação lexical (na matriz interna e externa) é regido por regras previstas no sistema linguístico. Por exemplo, a entrada no português de qualquer verbo vindo de outra língua obrigatoriamente é enquadrado na primeira conjugação terminando em -ar (tuitar, facebookar, deletar, printar, botar, shippar, etc).

Terminamos este debate lembrando que o Facebook apresenta bases da modalidade escrita e ao mesmo tempo marcas da modalidade oral. Assim como, uma tendência em misturar as duas modalidades, criando assim um instrumento novo de comunicação, em que 
se observa o oral, o escrito e sinais (moções) misturadas. A presença do inglês e do espanhol na fala dos internautas reforça a importância das duas línguas na política e no planejamento linguístico sustentadas pelos planos de ensino oferecidos pelo Ministério da Educação. As línguas estrangeiras modernas são obrigatórias no ensino e têm privilégio legal, o que faz com que as diversas línguas indígenas sejam relegadas ao esquecimento como se não existissem.

\section{Referências}

ALVES, I. M. O conceito de neologia: da descrição lexical à planificação linguística. Alfa. v. 40, São Paulo: UNESP, p.11-16, 1996.

. Neologismo: criação lexical. 2.ed. São Paulo: Ática, 2004.

ASSIS, A. B. G. de. Adaptações fonológicas na pronúncia de estrangeirismos do inglês por falantes de Português Brasileiro. 2007, 267f. (Dissertação). Mestrado em Linguística e Língua Portuguesa, Faculdade de Ciências e Letras, Araraquara, 2007.

BARBOSA, M. A. Léxico, produção e criatividade: processos do neologismo. São Paulo: Global, 1981.

BIDERMAN, M. T. C. A estruturação mental do léxico. In: BORBA, F. da S. (Org.). Estudos de filologia e linguística: em homenagem a Isaac Nicolau Salum. São Paulo: T. A. Queiroz, 1981. p. 131-145.

.Léxico e vocabulário fundamental. Alfa. v. 40, n.1, p.27-46, 1996.

.Teoria linguística: teoria lexical e linguística computacional. 2ed. São Paulo:

Martins Fontes, 2001.

BRASIL. Projeto de Lei 1676. Dispõe sobre a promoção, a proteção, a defesa e o uso da Língua Portuguesa e dá outras providências e é da autoria do Deputado Aldo Rebelo. Brasília: Câmara dos Deputados, 1999.

CAMACHO, B. F. Estudo comparativo de expressões idiomáticas do português do Brasil e de Portugal e do francês da França e do Canadá. (Dissertação). Mestrado em Estudos Linguísticos, Instituto de Biociências, Letras e Ciências Exatas, Universidade Estadual Paulista, São José do Rio Preto, 2008.

CARVALHO, N. Empréstimos linguísticos na língua portuguesa. São Paulo: Cortez, 2009. .; KRAMER, R. A linguagem no Facebook. In: SHEPHERD, T. G.; SALIÉS, T.

G. (Org.). Linguística da internet. São Paulo: Contexto, 2013. p. 77-94.

CITELLI, A. Palavras meios de comunicação e educação. São Paulo: Cortez, 2006. 
CORREIA, M. Produtividade lexical e ensino da língua. In: VALENTE, A. C.; PERREIRA, M. T. G. (Org.). Língua portuguesa: descrição e ensino. São Paulo: Parábola, 2011. p.223238.

CRYSTAL, D. Language and internet. Cambridge: CUP, 2004. A revolução da linguagem. Trad. Ricardo Quintana, Rio de Janeiro: Jorge Zahar, 2005.

GROSJEAN, F. Life with two languages: an introduction to bilingualism. Harvard University Press. 1982.

HADŽIAHMETOVIÜ-JURIDA, S. Some distinctive lexical features of netspeak. Jezikoslovlje. v.8, n², 2007, 193-210.

NEBOT, F.A. Los diccionarios de la academia (1713-1997) (I). In: . (Eds.). Cuestiones de lexicología y lexicografia. 3.ed. Madrid: Universidad Nacional de Educación a Distancia. 2001, p. 173-225. (Cuadernos de la UNED).

.Cuestiones de lexicologia y lexicografia. Madrid: UNED, 2003.

PETTER, M. O léxico compartilhado pelo português angolano, brasileiro e moçambicano. Veredas. v.9, Porto Alegre, p.61-81, 2008.

PEREIRA, N.F. Neologismos locucionais por empréstimos: ser thug life para stalkear o inglês nas redes sociais. Monografia. (Graduação em Letras) Universidade Estadual de Goiás, Pires do Rio, 2012.

RAJAGOPALAN, K. Como o internetês desafia a linguística. In: SHEPHERD, T. G.; SALIÉS, T. G.(Org.). Linguística da internet. São Paulo: Contexto, 2013. p.37-54.

SAPIR, E. Língua e ambiente. In: (Org.). Linguística como ciência. Ensaios. Livraria Acadêmica, 1969, p. 43-62.

SARDINHA, T. B. Variação entre registros da internet. In: SHEPHERD, T. G.; SALIÉS, T. G.(Org.). Linguística da internet. São Paulo: Contexto, 2013. p. 55-77.

SILVEIRA BUENO, F. da. Gramática normativa da língua portuguesa. São Paulo: Saraiva, 1994.

STEINBERG, M. Neologismos de língua inglesa. São Paulo: Nova Alexandrina, 2003.

TIMBANE, A.A. A variação e a mudança linguística da língua portuguesa em Moçambique. 2013, 318f. (Tese). Doutorado em Linguística e Língua Portuguesa. Faculdade de Ciências e Letras, Universidade Estadual Paulista. Araraquara, 2013. A lexicultura no português de Moçambique. Linguística: estudos e pesquisas, Catalão-GO, vol. 18, n. 2, p. 43-59, jul./dez. 2014a. 
A formação de palavras a partir de siglas e acrônimos estrangeiros na língua portuguesa. Verbum: Cadernos de Pós-Graduação. n. 6, p. 50- 68, 2014 b.

WELKER, H.A. Dicionários: uma pequena introdução à lexicografia. Brasília: Thesaurus, 2004. 